Tomasz Jurczyk

Uniwersytet Łódzki

\title{
Ku zjednoczeniu państwa Narzędzia chińskiej polityki wobec Tajwanu
}

Problem tajwański, jak określa się w Pekinie kwestię statusu prawnego Tajwanu, od 1949 r. pozostaje jednym z najważniejszych chińskich zagadnień politycznych. W szczególny sposób łączy on przy tym zagadnienia polityki wewnętrznej i zagranicznej, stanowiąc o własnej wyjątkowości. Od początku angażuje bowiem Stany Zjednoczone, a ważną areną rywalizacji rządów w Pekinie i Tajpej są stosunki międzynarodowe. Wykorzystywane w polityce ChRL wobec Tajwanu narzędzia służące realizacji celu zjednoczenia narodowego uwzględniają tę specyfikę, zachowując podobieństwo do tych używanych wobec innych państw.

Będący głównym obszarem zainteresowania niniejszego opracowania okres 2002-2012 obfitował w zmiany sytuacji politycznej zarówno po obydwu stronach Cieśniny Tajwańskiej, jak i w otoczeniu międzynarodowym. W ich wyniku istotnym modyfikacjom ulegały także narzędzia chińskiej polityki wobec Tajwanu. Dzięki prześledzeniu tych zmian łatwiejsze wydaje się wskazanie chińskich metod oddziaływania. W tym celu rozdział podzielono na trzy części. W pierwszej przedstawiono uzasadnienie podjęcia problematyki relacji ponad Cieśniną Tajwańską przy badaniach nad dyplomacją chińską. Następnie przybliżono cele polityki chińskiej wobec Tajwanu wraz z mechanizmem wykorzystywania poszczególnych środków. Trzecia część poświęcona została narzędziom stosowanym przez władze w Pekinie wobec strony tajwańskiej. Zostały one podzielone na cztery grupy, obejmujące środki ekonomiczne, polityczne, ideologiczno-kulturowe oraz wojskowe.

\section{Uzasadnienie}

Podjęcie tematyki polityki władz w Pekinie wobec Tajwanu w kontekście badań nad chińską polityką zagraniczną wymaga w pierwszej kolejności uzasadnienia celowości łączenia tych dwóch zagadnień, co wynika z ich formalnego 
rozdzielenia oraz stałego podkreślania wewnętrznego charakteru sporu w oficjalnych wypowiedziach ${ }^{1}$. Nasuwa się zatem pytanie, czy studiowanie polityki ChRL wobec Tajwanu przyczynia się do zrozumienia dyplomacji Pekinu. Twierdząca odpowiedź wynika z bardzo silnego, widocznego w kilku obszarach, aspektu międzynarodowego kwestii tajwańskiej, czyniącego z niej jedno z najważniejszych zagadnień chińskiej polityki zagranicznej.

Przede wszystkim należy zwrócić uwagę na leżące u podstawy dzisiejszego sporu niepełne rozstrzygnięcie chińskiej wojny domowej. Władze ChRL, od początku uważając obcą interwencję za przyczynę rozbicia Chin, wsparcie udzielane władzom tajwańskim przez Stany Zjednoczone traktują jako najważniejszą przeszkodę na drodze do ponownego zjednoczenia. Stąd też w Pekinie za większe zagrożenie od tajwańskich sił niepodległościowych uważa się obce wpływy na Tajwanie, bez pomocy których zwolennicy niepodległości nie rozwinęliby się.

Po drugie, zjednoczenie państwa dotyka najistotniejszych zagadnień współczesnej polityki chińskiej, takich jak modernizacja Chin i przywrócenie im należnego miejsca w świecie. Polityka Chin wobec Tajwanu w latach 2000-2012, w szczególności zaś zmiany, jakie w niej nastąpiły, również wpisują się w szerszy kontekst chińskiej strategii rozwoju. W tym względzie należy zwrócić uwagę na kojarzoną z nowym przywództwem Hu Jintao i premiera Wen Jiabao koncepcję „pokojowego wzrostu” Chin, zamienioną później na „pokojowy rozwój”. Włączono w nie kwestię tajwańską, czyniąc zjednoczenie ich integralną częściąą . Biorąc zaś pod uwagę, że obydwie wspomniane koncepcje miały w dużej mierze służyć rozwianiu obaw Zachodu oraz sąsiadów Chin, politykę wobec Tajwanu powiązano z polityką zagraniczną ChRL. W 2006 r. Hu Jintao wprost odniósł koncepcję ,pokojowego rozwoju” do relacji ponad Cieśniną Tajwańską, stwierdzając,

1 W tzw. komunikacie szanghajskim (1972) strona chińska stwierdziła m.in.: „(...) wyzwolenie Tajwanu jest wewnętrzną sprawą Chin, w którą żadne inne państwo nie może ingerować”. W stanowiących wykładnię chińskiej polityki wobec Tajwanu białych księgach, wydanych w 1993 i 1999 r., czytamy m.in.: „Należy podkreślić, iż kwestia tajwańska jest wyłącznie wewnętrzną sprawą Chin i nie posiada żadnych analogii do przypadków Niemiec i Korei, które były rezultatem porozumień międzynarodowych zawartych na koniec II wojny światowej” (1993); „Rozwiązanie kwestii tajwańskiej jest wewnętrzną sprawą Chin, która powinna zostać osiągnięta przez samych Chińczyków i nie ma potrzeby proszenia o pomoc sił zewnętrznych" (1999). Zob. Joint Statement Following Discussions with Leaders of the People's Republic of China, Shanghai, 27.02.1972, http://history. state.gov/historicaldocuments/frus1969-76v17/d203 [dostęp 15.10.2012]; The Taiwan Question and Reunification of China, Beijing, August 1993, http://www.china.org.cn/e-white/taiwan/index. htm [dostęp 15.10.2012] oraz The One-China Principle and the Taiwan Issue, Beijing, February 2000, http://english.gov.cn/official/2005-07/27/content_17613.htm [dostęp 15.10.2012].

2 Zhen Bijian, doradca najwyższych przywódców chińskich i autor koncepcji ,pokojowego wzrostu", pisząc na jesieni 2005 r. o pokojowych celach KPCh w XXI w. wymienił pokój międzynarodowy, harmonię wewnętrzną i pojednanie ponad Cieśniną Tajwańską. Zob. B. Zhen, Way that Communist Party of China Takes in 21st Century, http:/english.peopledaily.com.cn/200511/23/ eng20051123_223414.html [dostęp 15.06.2012]. 
iż „pokój i rozwój powinny stać się głównym obszarem relacji ponad Cieśniną Tajwańską oraz wspólnym celem mieszkańców zarówno Chin kontynentalnych, jak i Tajwanu"’. Wiąże się to z kluczową kwestią suwerenności, stanowiącą jedną z podstaw prowadzenia polityki zagranicznej.

Po trzecie, niektóre działania dyplomacji ChRL można wyjaśnić jedynie skierowaniem ich pośrednio do Tajwanu. Dotyczy to zwłaszcza państw, które utrzymują stosunki dyplomatyczne z Tajpej bądź skłaniają się ku temu. Sfera polityki międzynarodowej stanowi bowiem jeden z najważniejszych obszarów rywalizacji ponad Cieśniną Tajwańską, a izolacja międzynarodowa jest, obok groźby użycia siły oraz zachęt ekonomicznych, jednym spośród podstawowych elementów chińskiej strategii zjednoczeniowej. Najczęściej działania chińskie polegały na zaoferowaniu danemu krajowi pomocy rozwojowej o większej wartości niż ta proponowana przez Tajwańczyków, przy czym ogłoszenie nawiązania relacji dyplomatycznych następowało nierzadko w momencie ważnym z punktu widzenia relacji ponad Cieśniną Tajwańską ${ }^{4}$. Związki z bieżącym stanem stosunków chińsko-tajwańskich były również widoczne po 2008 r., kiedy wraz z ich poprawą, w imię podtrzymania dobrego klimatu, Chiny nie zdecydowały się na nawiązanie stosunków dyplomatycznych z państwami uznającymi Republikę Chińską. Pekin, dążąc do odebrania Tajwanowi uznania międzynarodowego, odwoływał się przy tym nie tylko do zachęt ekonomicznych, ale również do swojej pozycji politycznej. Tak było w przypadku Macedonii w 2001 r., kiedy Pekin dał do zrozumienia, że może wykorzystać swój status stałego członka Rady Bezpieczeństwa ONZ do zablokowania wysłania misji pokojowej, jeżeli Skopje nie zrezygnuje z uznawania rządu w Tajpej5. Czynnik tajwański stanowi zatem istotny element polityki chińskiej wobec państw Afryki, Ameryki Łacińskiej i Karaibów oraz Oceanii.

Nie można również pominąć faktu, że Chiny okresowo same przenoszą kwestię tajwańską na poziom relacji międzynarodowych, wykorzystując inne państwa do wywierania nacisku na władze w Tajpej ${ }^{6}$. W szczególności dotyczyło to Stanów

${ }^{3}$ Hu Jintao zai Renmin Dahui jian Lian Chan shi jianghua quanwen [Pełny tekst wystąpienia Hu Jintao podczas spostkania z Lien Chanem w gmachu OZPL], http://tw.people.com.cn/ GB/14810/4302233.html [dostęp 20.11.2012].

4 Tak było przy ogłoszeniu nawiązania stosunków dyplomatycznych pomiędzy Chinami i Nauru w 2001 r., co zbiegło się z objęciem przez prezydenta Chen Shui-biana przewodnictwa w Demokratycznej Partii Postępowej. Zob. Ch. Chao, Ch. Hsu, China Isolates Taiwan, [w:] E. Friedman, China's Rise, Taiwan's Dilemmas and International Peace, Routledge, New York 2006, s. 53-54.

5 Cz. Tubilewicz, Taiwan and Post-Communist Europe. Shopping for Allies, Routledge, New York 2007, s. 148-154.

${ }^{6}$ Było to szczególnie widoczne w okresie poprzedzającym kampanię wyborczą przed wyborami prezydenckimi na Tajwanie w 2004 r. Po pierwsze, od lata 2003 r. Pekin zamiast intensyfikacji własnych działań bezpośrednich zaczął wykorzystywać Stany Zjednoczone do wywierania presji. Po drugie, problematyka tajwańska była w tamtym okresie eksponowana podczas wizyt państwowych najwyższych przywódców chińskich. Po trzecie, zaczęto również wysyłać kierownictwo Biura ds. Tajwanu, w tym jego dyrektora, z misjami dyplomatycznymi do Stanów Zjednoczonych, Unii 
Zjednoczonych, które jako faktyczny gwarant niezależności tajwańskiej miały największe możliwości wpływania na sytuację na Tajwanie. Co więcej, wydaje się, że władze w Pekinie uważały aspekt międzynarodowy kwestii tajwańskiej za zyskujący na znaczeniu, o czym mogą świadczyć zmiany dokonywane w kierownictwie ${ }^{7}$. Tym bardziej zasadne jest uwzględnienie polityki wobec Tajwanu w analizie chińskiej polityki międzynarodowej. Choć niewątpliwie stale należy mieć na uwadze specyfikę relacji ponad Cieśniną Tajwańską, zarówno jeżeli chodzi o ich wymiar instytucjonalny, charakter prawny (nie są uregulowane, tak jak stosunki dyplomatyczne), przedmiot relacji (nie obejmują dziedzin obecnych w kontaktach z innymi partnerami) oraz znaczenie Tajwanu dla Chin.

\section{Cele polityki i użycie narzędzi służących ich osiągnięciu}

Od 1949 r. celem polityki władz ChRL wobec Tajwanu niezmiennie pozostaje rozciągnięcie kontroli nad wyspą oraz potwierdzenie jedności Chin, w tym wyłącznego uznania dla rządu w Pekinie. Jeszcze przed formalnym powstaniem nowego państwa chińskiego, wiosną 1949 r. Mao Zedong zadecydował o zbrojnym podbiciu Tajwanu kontrolowanego przez rząd kuomintangowski, który właśnie tam zamierzał przegrupować własne siły przed odbiciem Chin kontynentalnych z rąk komunistów. W realizacji tego celu przeszkodził jednak wybuch wojny koreańskiej i amerykańskie zaangażowanie na rzecz powstrzymania komunistów w Azji, czemu miał służyć m.in. sojusz z Republiką Chińską. W efekcie tego sytuacja w Cieśninie Tajwańskiej uległa zamrożeniu na kolejne dziesięciolecia, a metody wojskowe pozostały jedynymi środkami osiągnięcia zakładanego przez Pekin celu.

Zmiana nastąpiła dopiero w 1979 r., kiedy ChRL wysunęła propozycję pokojowego zjednoczenia. W kolejnych latach nowa oferta chińska dla Tajwanu została doprecyzowana w postaci tzw. polityki jeden kraj, dwa systemy, opierającej się na szeregu zachęt skierowanych do strony tajwańskiej i zakładającej przyznanie Tajwanowi daleko posuniętej autonomii w ramach ChRL. Doszło zatem wówczas do fundamentalnej rewizji, jeżeli chodzi o środki osiągnięcia celu polityki

Europejskiej oraz Japonii, podczas których miał on informować o stanowisku chińskim wobec aktualnej sytuacji w Cieśninie Tajwańskiej. Zob. Ch. Lin, More Carrot Than Stick: Beijing 's Emerging Taiwan Policy, „China Security” 2008, vol. 4, no. 1, s. 6.

7 Na przykład do Grupy Kierowniczej ds. Tajwanu, kolegialnego ciała koordynującego politykę chińską wobec Tajwanu, dołączyli w 2008 r. Dai Bingguo oraz Wang Yi, byli wiceministrowie spraw zagranicznych. Drugi z wymienionych stanął przy tym w tym samym roku na czele Biura ds. Tajwanu. Zob. W. Chang, Ch. Chao, Managing Stability in the Taiwan Strait: Non-Military Policy towards Taiwan under Hu Jintao, „Journal of Current Chinese Affairs” 2009, vol. 38, no. 3, s. 107-108 oraz A. Miller, The CCP Central Committee's Leading Small Groups, „China Leadership Monitor" 2008, no. 26, s. 12. 
chińskiej wobec Tajwanu. Kolejna modyfikacja, dokonana po zakończeniu zimnej wojny, dotyczyła z kolei faktycznego wyróżnienia priorytetów krótko- i średniookresowych. O ile w 1979 r., zarówno w Pekinie, jak i w innych stolicach zakładano rychłe rozwiązanie kwestii tajwańskiej (osamotniona i izolowana wyspa miała nie mieć innego rozwiązania jak tylko zjednoczenie), to 10 lat później stało się jasne, że ostateczne rozstrzygnięcie znacznie się oddaliło.

W Pekinie zaczęto zatem myśleć przede wszystkim o zapobieżeniu ogłoszenia przez Tajwan formalnej niepodległości, a dopiero w dalszej kolejności o zjednoczeniu. Tym bardziej, że od przełomu lat 80. i 90. XX w. charakter samych relacji ponad Cieśniną Tajwańską uległ fundamentalnym zmianom ${ }^{8}$. Chińska polityka wobec Tajwanu po zakończeniu zimnej wojny stanowiła zatem kombinację elementów dyplomatycznych, ekonomicznych, politycznych oraz wojskowych. Dyplomatycznie Pekin kontynuował dążenia do izolacji międzynarodowej Tajwanu, ekonomicznie zmierzał ku integracji gospodarczej obydwu stron Cieśniny Tajwańskiej, politycznie chciał wzmocnienia podziałów wewnątrz Tajwanu, wojskowo utrzymywał presję. Wszystkie wymienione elementy były przy tym ze sobą ściśle powiązane i podporządkowane nadrzędnemu celowi zjednoczenia państwowego, decydując tym samym o skomplikowanym połączeniu polityki wewnętrznej i zagranicznej.

Należy przy tym zwrócić uwagę, że opisane powyżej podejście, polegające na łącznym stosowaniu zachęt oraz gróźb, wywodzi się z koncepcji tzw. polityki zjednoczonego frontu. Nawiązując do tworzonych przed II wojną światową frontów ludowych, zakłada ona odwoływanie się przez partię komunistyczną do tych środowisk, które, choć obce, ideologicznie podzielają jednak pogląd na to, kto aktualnie jest największym wrogiem. W praktyce podejście to zakłada zebranie jak najszerszej grupy koalicjantów wokół stosunkowo ograniczonych celów, przy jasnym wskazaniu wrogów9. W omawianym okresie był to szczególnie istotny element polityki wobec Tajwanu, gdyż po 2000 r. pojawił się znaczący partner do rozmów, jakim była znajdująca się do 2008 r. w opozycji Partia Narodowa (Kuomintang) wraz ze swoimi mniejszymi sojusznikami ${ }^{10}$. W dużej mierze podzielały

8 Po zakończeniu zimnej wojny zmianie uległ paradygmat sporu pomiędzy obiema stronami Cieśniny Tajwańskiej. Nie dotyczy on już bowiem tego, kto ma prawo do reprezentowania Chin w stosunkach międzynarodowych, władze Republiki Chińskiej faktycznie wyrzekły się również roszczeń odnośnie do sprawowania władzy nad Chinami kontynentalnymi, a na samym Tajwanie zyskiwał na sile ruch niepodległościowy, podkreślający odrębność Tajwańczyków. Zob. C.L. Hamrin, Z. Wang, The Floating Island: Change of Paradigm on the Taiwan Question, „Journal of Contemporary China" 2004, vol. 13 (39), s. 339-349.

9 F.C. Teiwes, The Establishment and Consolidation of the New Regime, 1949-1957, [w:] R. MacFarquhar (red.), The Politics of China: Sixty Years of The People's Republic of China, Cambridge University Press, New York 2011, s. 27.

${ }_{10} \mathrm{~W}$ odniesieniu do Tajwanu jest ona realizowana poprzez odwoływanie się władz w Pekinie bezpośrednio do mieszkańców Tajwanu (co w dużej mierze pozwala także uniknąć leżącego 
one obawy związane z dojściem do władzy Chen Shui-biana i dalszym rozwojem tożsamości tajwańskiej. Efektem współpracy było niewiązanie przez stronę chińską zachęt oferowanych po 2005 r. z wewnętrznymi wydarzeniami politycznymi na Tajwanie oraz z działaniami samego prezydenta ${ }^{11}$. Dzięki temu Pekin zwiększał presję wywieraną na rząd tajwański poprzez pokazanie Tajwańczykom słabości władz i siły opozycji. Zapoczątkowany w ten sposób dialog międzypartyjny był kontynuowany po ponownym przejęciu władzy przez KMT w 2008 r.

\section{Narzędzia}

\section{A. Gospodarcze}

W zakresie stosowania narzędzi ekonomicznych należy zwrócić uwagę, iż w omawianym okresie wiele z narzędzi wykorzystywanych wobec innych podmiotów nie mogło być użytych wobec Tajwanu z racji zamknięcia przez Tajpej dla strony chińskiej niektórych obszarów wymiany gospodarczej. Przez prawie cały omawiany okres relacje gospodarcze ponad Cieśniną Tajwańską w praktyce ograniczały się zatem wyłącznie do handlu oraz inwestycji tajwańskich w Chinach kontynentalnych. Dopiero po 2008 r. władze tajwańskie umożliwiły ograniczone inwestowanie na wyspie przez podmioty chińskie i rozpoczęły proces otwierania się na współpracę w dziedzinie finansów. Do końca 2012 r. obszary te nie rozwinęły się jednak w znaczącym stopniu ${ }^{12}$.

Warto również podkreślić, że relacje gospodarcze ponad Cieśniną Tajwańską stanowią rzadki przypadek, kiedy rywale polityczni rozwijają wzajemny handel oraz inwestycje. Co więcej, Tajwan, jako strona słabsza pod względem ogólnego potencjału, jest dużo bardziej zależny od silniejszych Chin. Obok przewagi wynikającej z samej asymetrii stopnia uzależnienia, Chiny mają również duże możliwości dostarczania korzyści poszczególnym tajwańskim grupom społecznym w zależności od potrzeb politycznych (realizując politykę zjednoczonego frontu). Dzięki temu strona chińska dysponuje instrumentami zarówno negatywnego, jak i pozytywnego oddziaływania na Tajwan ${ }^{13}$.

u podstaw sporu problemu wzajemnego statusu władz w Pekinie i Tajpej), przy uznaniu zwolenników niepodległości Tajwanu za głównych przeciwników.

11 J. Wang, Hu Jintao's ,, New Thinking” on Cross-Strait Relations, „American Foreign Policy Interests" 2007, vol. 29, 2007, s. 30-31.

12 Po formalnym umożliwieniu przez Tajwan w połowie 2009 r. chińskich inwestycji bezpośrednich w wybranych obszarach w ciągu 3 lat, osiągnęły one łączną wartość zaledwie nieco ponad 300 mln dolarów. Zob. Cross-Strait Economic Statistics Monthly, no. 234, 2-13, Mainland Affairs Council.

13 Dzięki powstałym w ciągu trzech dekad powiązaniom gospodarczym Chiny zyskały znaczące środki nacisku na Tajwan. Wynikają one z faktu, że zależność eksportowa jest groźniejsza 
Pekin nie ukrywa przy tym faktu politycznego wykorzystywania relacji gospodarczych z Tajwanem. Jeszcze w 1990 r. przewodniczący ChRL Yang Shangkun powiedział: „Powinniśmy promować integrację polityczną poprzez gospodarkę, zmusić władze tajwańskie do rozmów z nami poprzez manipulowanie tajwańską opinią publiczną oraz prowadzić wymianę pomiędzy obiema stronami w kierunku służącym zjednoczeniu ojczyzny”. W szerszej perspektywie ujmują to zaś słowa odnoszące się do całościowej strategii wobec Tajwanu: „blokować Tajwan dyplomatycznie, powstrzymywać Tajwan wojskowo i przeciągnąć Tajwan ekonomicznie"14 (w tym ujęciu środki ekonomiczne są traktowane jako zachęta). Wiąże się to $\mathrm{z}$ tym, że po faktycznym rozstrzygnięciu rywalizacji na polu dyplomatycznym oraz ze względu na zbyt wysokie koszty konfliktu zbrojnego, sfera relacji gospodarczych stała się na początku lat 90 . jednym z głównych obszarów rywalizacji obydwu stron ${ }^{15}$. W tym kontekście dla Pekinu ważne jest stworzenie takiej sytuacji, w której każda opcja inna niż zjednoczenie stanie się dla Tajwanu zbyt kosztowna (plan minimum), czy wręcz skłoni do zjednoczenia (plan maksimum).

W tym miejscu należy jednak zauważyć, że przy ewentualnym użyciu środków ekonomicznych o charakterze negatywnym ${ }^{16}$ Chiny ograniczają czynniki zewnętrzne i wewnętrzne. Przede wszystkim zarówno inwestycje tajwańskie, jak i handel ponad Cieśniną Tajwańską stanowią w dużej części element ogólnoświatowych sieci produkcyjnych, przez co zakłócenia w jego funkcjonowaniu dotknęłyby szereg innych państw, ze Stanami Zjednoczonymi na czele. Poza tym tajwańskie inwestycje w Chinach są prawie w całości zlokalizowane na kilku obszarach, przez co lokalnie odgrywają istotną rolę (choć w wymiarze całych Chin

od importowej, a lokowanie bezpośrednich inwestycji zagranicznych u rywala politycznego bardziej ryzykowne od jakiekolwiek zależności handlowej - w obydwu przypadkach trudno w krótkim czasie zastąpić odbiorcę towarów i inwestycji. Zob. T.J. Cheng, China-Taiwan Economic Linkage. Between Insulation and Superconductivity, [w:] N. Bernkopf Tucker (red.), Dangerous Strait. The U.S. -Taiwan-China Crisis, Columbia University Press, New York 2005, s. 105.

14 Słowa te przypisuje się byłemu wicepremierowi i ministrowi spraw zagranicznych ChRL Qian Qichenowi. Według mediów hongkońskich miał je wypowiedzieć w 1993 r., podczas jednego ze spotkań z urzędnikami wyższego szczebla zajmującymi się sprawami tajwańskimi. Za: Y. Chu, The Political Economy of Taiwan's Mainland Policy, [w:] S. Zhao (red.), op. cit., s. 182 i 194.

15 J.Q. Tian, Government, Business, and the Politics of Interdependence and Conflict across the Taiwan Strait, Routledge, New York 2006, s. 3.

16 W literaturze najczęściej wskazuje się w tym względzie użycie przez Chiny sankcji (eksportowych i importowych), zamrożenie bądź nacjonalizację zasobów tajwańskich, działania przeciw wybranym osobom bądź firmom (np. popierającym nieakceptowane przez Pekin siły polityczne), destabilizację gospodarki tajwańskiej, umyślne zakłócanie normalnego funkcjonowania firm tajwańskich działających w Chinach oraz możliwość „drenażu” gospodarczego (przejęcie najważniejszych firm i technologii). Za ważne narzędzie ekonomiczne można także uznać wysyłanie sygnałów do państw trzecich grożących zerwaniem współpracy gospodarczej z Chinami w przypadku działań niezgodnych ze stanowiskiem Pekinu w odniesieniu do polityki wobec Tajwanu. Zob. M.S. Tanner, Chinese Economic Coercion Against Taiwan. A Tricky Weapon to Use, RAND Corporation, Santa Monica 2007, s. 15-19. 
niewielką). Niewątpliwie świadomość tych ograniczeń wpływa na postrzeganą skuteczność oddziaływania ${ }^{17}$.

W praktyce, pomimo zapowiedzi niektórych przedstawicieli władz chińskich, groźby takie w omawianym okresie nie zostały zrealizowane. Nawet przy okazji kampanii prezydenckich w 2000 i 2004 r., kiedy starano się wywrzeć presję na biznesmenów tajwańskich wspierających Chen Shui-biana, nieuleganie chińskim żądaniom nie pociągnęło za sobą negatywnych konsekwencji przy prowadzeniu działalności gospodarczej ${ }^{18}$. W latach 2000-2008, pomimo napięć politycznych, wymiana gospodarcza pomiędzy Tajwanem i Chinami kontynentalnymi nie tylko nie ucierpiała, ale dynamicznie rosła (patrz tabela 8.1). Okresowe spadki spowodowane były zaś czynnikami zewnętrznymi, przede wszystkim spadkiem koniunktury na rynkach światowych. Można zatem stwierdzić, że korzystanie przez Chiny z ekonomicznych środków nacisku na Tajwan pozostawało w omawianym okresie jedynie potencjalnym narzędziem, z którego nie skorzystano.

Niewątpliwie chińska strategia jest obliczona głównie na wytworzenie głębokich więzów gospodarczych pomiędzy obydwiema stronami Cieśniny Tajwańskiej. W tym celu już w pierwszej połowie lat 80 . zaczęto wprowadzać specjalne uregulowania, dzięki którym stworzono system prawny formalnie gwarantujący tajwańskim firmom ochronę inwestycji ${ }^{19}$ oraz wprowadzający szereg udogodnień niedostępnych dla innych podmiotów ${ }^{20}$. Przede wszystkim dotyczyły one swobody prowadzenia działalności (np. wyłączały z wymogu tworzenia spółek joint venture z lokalnymi partnerami, otwierały branże niedostępne dla innych inwestorów itd.) oraz zwolnień celnych, podatkowych czy z posiadania licencji importowych. Korzystniejsze niż dla innych partnerów zewnętrznych były także regulacje dotyczące zatrudniania pracowników z Tajwanu oraz płacenia przez nich podatków i ce ${ }^{21}$. Specyficzną zachętą stało się również zachowanie dyskrecji przez chińskie władze lokalne, istotne, jeżeli weźmiemy pod uwagę omijanie bądź łamanie przez firmy z Tajwanu rodzimych przepisów ograniczających inwestycje w Chinach.

Powyższe elementy (utrzymywane również w omawianym okresie) z pewnością przyczyniły się do dynamicznego rozwoju relacji gospodarczych ponad

17 T.J. Cheng, op. cit., s. 93-130.

18 M.S. Tanner, op. cit., s. 112-120.

19 Właśnie inwestycje, a nie początkowo wspierany handel, stały się na przełomie lat 80. i 90. preferowanym przez władze chińskie kierunkiem rozwoju relacji gospodarczych ponad Cieśniną Tajwańską. Aktywnie zabiegano o inwestycje głównie ze względu na priorytety rozwoju własnej gospodarki, którą chciano podnieść na wyższy poziom. Służyło temu m.in. podnoszenie już i tak stosunkowo wysokich ceł importowych wraz ze wzrostem stopnia przetworzenia produktu (a w takiej właśnie produkcji specjalizowały się przedsiębiorstwa tajwańskie). Zob. J.Q. Tain, Government, Business, and the Politics of Interdependence and Conflict Across the Taiwan Strait, Palgrave Macmillan, New York 2006, s. 62.

${ }^{20}$ K.M. Sutter, Business Dynamism Across the Taiwan Strait: The Implications for Cross-Strait Relations, „Asian Survey” 2002, vol. 42, no. 3, s. 524.

21 M.S. Tanner, op. cit., s. 38. 
Cieśniną Tajwańską, należy jednak umieścić je we właściwym kontekście. Z jednej strony, kapitał tajwański oraz doświadczenie Tajwańczyków miały wspomóc rozwój gospodarczy Chin. W szczególności dotyczyło to początkowych etapów reform, kiedy firmy zachodnie nie odgrywały jeszcze w Chinach znaczącej roli ${ }^{22}$. $\mathrm{Z}$ drugiej zaś strony, biznesmeni tajwańscy mieli stanowić grupę społeczną, która poprzez związanie swojego osobistego bytu ze stanem relacji ponad Cieśniną Tajwańską będzie dążyć do realizowania na Tajwanie oczekiwanych przez Chiny rozwiązań politycznych służących zjednoczeniu państwa. Oczekiwania te w dużej mierze okazały się nierealne, gdyż przedsiębiorcy nie zarzucili własnych poglądów politycznych, a lobbing, jaki uprawiali na Tajwanie, ograniczał się do spraw gospodarczych. Stało się to szczególnie widoczne w 2004 r., po reelekcji Chen Shui-biana.

W praktyce dopiero od 2005 r. zaczęto w Pekinie przywiązywać większą wagę do bezpośredniego wykorzystania narzędzi ekonomicznych w celach politycznych. Przede wszystkim miały one służyć nie tylko przedsiębiorcom, ale jak najszerszemu kręgowi odbiorców, w tym w szczególności grupom tradycyjnie negatywnie nastawionym do Chin (np. rolnikom z południowego Tajwanu, stanowiącym twardy elektorat Demokratycznej Partii Postępowej). W trakcie wizyt przywódców opozycji tajwańskiej w Chinach zapowiedziano m.in. liberalizację handlu produktami rolnymi, wsparcie dla rozwoju turystyki chińskiej na Tajwan czy ułatwienia dla Tajwańczyków mieszkających w Chinach, w tym dla studentów tajwańskich na chińskich uczelniach ${ }^{23}$. Patrząc na powyższe pomysły, można jednak zauważyć, że tylko część z nich była do zrealizowania jednostronnie przez Chiny. Pozostałe wymagały współpracy ze strony rządu w Tajpej.

Najważniejszym elementem wydaje się jednak tolerowanie przez Chiny znacznego deficytu w dwustronnej wymianie handlowej, który w latach 20102011 sięgnął prawie 50 mld USD rocznie i umożliwiał Tajwanowi utrzymywanie dodatniego bilansu handlowego (patrz tabela 8.1). Choć w niemałej mierze wynika to $\mathrm{z}$ charakteru inwestycji tajwańskich w Chinach (będących częścią globalnych łańcuchów produkcyjnych), to władze w Pekinie w większym stopniu otwierają się na produkty tajwańskie, niż dążą do dostępu do rynku tajwańskiego. Trend ten jest wyraźnie zauważalny choćby w postanowieniach Ramowej Umowy o Współpracy Gospodarczej z 2010 r. (ECFA, Economic Cooperation

22 B. Naughton, The Chinese Economy. Transitions and Growth, The MIT Press, CambridgeLondon 2006, s. 401-424.

${ }_{23}$ Taipei Urged to Talk on Mainland Gifts, TAO Spokesperson's Remarks, Beijing, 2.06.2005, http://www.gwytb.gov.cn/en/SpokespersonRemarks/201103/t20110316_1788166.htm [dostęp 15.12.2012; New Rules Aim to Make Taiwanese Feel at Home, TAO Spokesperson's Remarks, Beijing, 16.06.2005, http://www.gwytb.gov.cn/en/SpokespersonRemarks/201103/t20110316_1788173. htm [dostęp 15.12.2012]; Taiwan Students on Mainland Given Level Fees, TAO Spokesperson's Remarks, Beijing, 25.08.2005, http://www.gwytb.gov.cn/en/SpokespersonRemarks/201103/ t20110316_1788181.htm [dostęp 15.12.2012]. 
Framework Agreement), która będąc rodzajem umowy o wolnym handlu, docelowo przewiduje otwarcie rynku chińskiego dla 539 kategorii tajwańskich produktów wobec 267 kategorii produktów chińskich zwolnionych z cła na Tajwanie (biorąc pod uwagę wartość, różnica jest jeszcze większa i wynosi 13,8 do 2,8 mld USD) ${ }^{24}$. Decyzja ta niewątpliwe jest motywowana politycznie i ma na celu łagodzenie obaw części tajwańskich wyborców obawiających się zalania wyspy produktami chińskimi.

Szczególnym narzędziem stały się także misje zakupowe, jakie zaczęto wysyłać na Tajwan w 2009 r. Były to chińskie delegacje szczebla prowincji (shengji jiaoliutuan), składające się nawet z kilkuset członków (głównie przedstawicieli przedsiębiorstw), którym przewodzili gubernatorzy bądź sekretarze KPCh. Miały one na celu głównie rozbudowywanie więzi gospodarczych, choć służyły również wspieraniu wymiany kulturalnej. Przede wszystkim, poprzez zakupy w branżach odczuwających skutki kryzysu gospodarczego lub tradycyjnie popierających DPP, miały one realizować politykę zjednoczonego frontu, dodatkowo przyczyniając się do integrowania wyżej wymienionych z chińskim rynkiem wewnętrznym. O ich specjalnej roli politycznej może przy tym świadczyć wstrzymanie tej inicjatywy na przełomie 2011 i 2012 r., co było spowodowane toczącą się na Tajwanie kampanią przed wyborami prezydenckimi, a także fakt konieczności uzyskania przez każdą delegację zezwolenia Biura ds. Tajwanu²5.

Tabela 8.1.

Wymiana handlowa ponad Cieśniną Tajwańską (mld USD)

\begin{tabular}{|c|c|c|c|c|}
\hline Rok & $\begin{array}{c}\text { Tajwański eksport } \\
\text { do Chin }\end{array}$ & $\begin{array}{c}\text { Tajwański import } \\
\text { z Chin }\end{array}$ & $\begin{array}{c}\text { Bilans Chin w dwu- } \\
\text { stronnej wymiani } \\
\text { handlowej }\end{array}$ & $\begin{array}{c}\text { Dwustronna } \\
\text { wymiana } \\
\text { handlowa }\end{array}$ \\
\hline 1 & 2 & 3 & 4 & 5 \\
\hline 2000 & 25,0 & 6,2 & $-18,8$ & 31,2 \\
\hline 2001 & 25,6 & 5,9 & $-19,7$ & 31,5 \\
\hline 2002 & 31,5 & 8,0 & $-23,5$ & 39,5 \\
\hline 2003 & 38,3 & 11,0 & $-27,2$ & 49,3 \\
\hline 2004 & 48,9 & 16,8 & $-32,1$ & 65,7 \\
\hline 2005 & 56,3 & 20,1 & $-36,2$ & 76,4 \\
\hline
\end{tabular}

${ }^{24}$ Early Harvest List for Trade in Goods and Tariff Reduction Arrangements (Source: Industrial Development Bureau, MOEA), Mainland Affairs Council, http://www.mac.gov.tw/ct.asp?xItem $=85851 \&$ ctNode $=5921 \& \mathrm{mp}=3$ [dostęp 10.11.2011].

25 S. Chien, Ch. Hsieh, Political Economy of Taiwan-China Transnational Interactions - A Perspective of Provincial Exchange and Procurement Delegations, web.bp.ntu.edu.tw/DevelopmentStudies/Data/ACDS_2nd_B11.pdf [dostęp 19.01.2013]. 


\begin{tabular}{|c|c|c|c|c|}
\hline 1 & 2 & 3 & 4 & 5 \\
\hline 2006 & 63,3 & 24,8 & $-38,5$ & 88,1 \\
\hline 2007 & 74,2 & 28,0 & $-46,2$ & 102,2 \\
\hline 2008 & 74,0 & 31,4 & $-42,6$ & 105,4 \\
\hline 2009 & 62,1 & 24,5 & $-37,6$ & 86,6 \\
\hline 2010 & 84,8 & 35,9 & $-48,9$ & 120,7 \\
\hline 2011 & 91,1 & 43,6 & $-47,5$ & 134,7 \\
\hline
\end{tabular}

Żródło: Cross-Strait Economic Statistics Monthly, Mainland Affairs Council (www.mac.gov. tw) oraz obliczenia własne autora.

\section{B. Polityczne}

\section{Instytucjonalizacja relacji}

Relacje ponad Cieśniną Tajwańską nie mają charakteru przewidzianego w prawie międzynarodowym dla relacji międzypaństwowych, przez co brak jest norm regulujących je, są również słabo zinstytucjonalizowane. Wynika to ze sporu pomiędzy obydwiema stronami odnośnie do charakteru wzajemnych stosunków. Istniejące uregulowania wewnętrzne w Chinach kontynentalnych i na Tajwanie, a także nieliczne porozumienia dwustronne zawierane przez podmioty upoważnione przez rządy, w dużej mierze zaledwie starały się podążać za żywiołowo rozwijającą się od końca lat 80 . XX w. wymianą gospodarczą i międzyludzką. W ten sposób w latach 1990-1991 stworzono system, którego podstawą stał się dialog prowadzony za pośrednictwem formalnie pozarządowej tajwańskiej Fundacji Wymiany ponad Cieśniną Tajwańską (Haixia Jiaoliu Jijinhui; SEF, Straits Exchange Foundation) i chińskiego Stowarzyszenia Relacji ponad Cieśniną Tajwańską (Haixia Liang'an Guanxi Xiehui; ARATS, Association for Relations Across the Taiwan Straits). Bazował on na dorozumianym uznaniu istnienia jednego państwa chińskiego, inaczej nazywanego przez każdą ze stron. Dzięki temu uniknięto sporów związanych z formalnym definiowaniem relacji Tajwanu i Chin kontynentalnych, skupiając się na rozwiązywaniu praktycznych problemów związanych z rosnącą liczbą Tajwańczyków udających się na drugi brzeg Cieśniny w celach prywatnych i zawodowych.

O ile w latach 1993-1998 odbyło się ponad 20 rund rozmów SEF-ARATS, w tym dwa spotkania na szczycie z udziałem przewodniczących obydwu organizacji (w 1993 r. w Singapurze oraz w 1998 r. w Szanghaju) ${ }^{26}$, to w latach 1999-2008 kontakty te były zamrożone. Wynikało to przede wszystkim z braku zaufania władz chińskich do przywódców tajwańskich, najpierw Lee Teng-hui'a,

${ }^{26}$ Ch. Su, Taiwan's Relations with Mainland China. A Tail Wagging Two Dogs, Routledge, London-New York 2009, s. 18-21. 
a później Chen Shui-biana. Wyjątkiem w okresie 2000-2008 było jedynie wypracowanie tzw. formuly negocjacji Makao (od miejsca rozmów). Wiązała się ona z jednym z najważniejszych zagadnień poruszanych w omawianym okresie, jakim była kwestia przywrócenia bezpośrednich połączeń lotniczych pomiędzy Tajwanem i Chinami kontynentalnymi ${ }^{27}$. Niewątpliwie pierwotnie obie strony chciały wykorzystać tę kwestię do realizacji celów politycznych (Chiny do uznania przez Tajwan zasady jednych Chin jako warunku wstępnego do rozmów, Tajwan do wznowienia rozmów SEF-ARATS bez warunków wstępnych), z czasem jednak obie strony ustąpiły, dzięki czemu w 2005 r. zrealizowano loty czarterowe w czasie chińskiego Nowego Roku. Wypracowane wówczas rozwiązanie, oparte na przystąpieniu bez wstępnych warunków do realizowanych przez upoważnione podmioty prywatne rozmów (bez udziału przedstawicieli SEF i ARATS, ale dopuszczające innych urzędników), stało się podstawą do negocjowania porozumień w sferze gospodarczej o charakterze technicznym i niebudzących kontrowersji ${ }^{28}$.

Chiny w okresie rządów Chen Shui-biana na Tajwanie (2000-2008) nie były przy tym bierne i aktywnie rozwijały taktykę zjednoczonego frontu. Było to możliwe dzięki zmianom w polityce wewnętrznej Tajwanu, które spowodowały, że liczące się tajwańskie siły polityczne były skłonne podjąć rozmowy z Pekinem. Nastąpiła wówczas instytucjonalizacja dialogu międzypartyjnego pomiędzy Komunistyczną Partią Chin i tajwańskimi partiami opozycyjnymi, na czele z Kuomintangiem. Najbardziej widocznym jej aspektem stało się Forum Gospodarcze, Handlowe i Kulturalne Cieśniny Tajwańskiej (Liang 'an Jingmao Wenhua Luntan), znane również jako Forum Kumintang-KPCh, formalnie organizowane przez powiązaną z Kuomintangiem National Policy Foundation (Guozheng Yanjiu Jijinhui) oraz utworzone przez partyjne i rządowe Biuro ds. Tajwanu ChRL Centrum Badań Relacji ponad Cieśniną Tajwańską (Haixia Liang'an Guanxi Yanjiu Zhongxin). W latach 2006-2012 zorganizowano łącznie 8 spotkań w różnych miastach chińskich. Ich efektem były rekomendacje dla władz, w których wskazywano konkretne działania mające na celu wsparcie rozwoju wymiany ponad Cieśniną Tajwańską. Warto przy tym zauważyć, że nawet po 2008 r. i ponownym objęciu władzy przez Kuomintang kanał ten nie tylko nie stracił na znaczeniu,

27 Choć wezwanie do uregulowania tej kwestii pojawiło się już w odezwie chińskiej z 1979 r., to dopiero stale rosnąca od lat 90 . XX w. liczba kontaktów międzyludzkich oraz gospodarczych spowodowała, że zarówno Pekin, jak i Tajpej zainteresowały się pozytywnym rozwiązaniem problemu. Na przeszkodzie stało jednak głównie stanowisko chińskie, domagające się uznania przez Tajwan zasady jednych Chin jako podstawy do rozpoczęcia rozmów oraz traktowania lotów jako połączeń krajowych. Zob. China's Policy on „Three Direct Links” Across the Taiwan Straits, Beijing, December 2003, http://www.china.org.cn/e-white/20050816/index.htm [dostęp 20.07.2012].

28 Pierwsze tego rodzaju loty wykonały w 2003 r. tajwańskie linie lotnicze. Ich podstawą była jednak jednostronna zgoda Chin, które liczyły na przeprowadzenie analogicznej operacji przez chińskie linie w kolejnym roku. 
ale stał się jednym z najważniejszych środków komunikacji i prowadzenia dialogu ponad Cieśniną Tajwańską. Z jednej strony, formalnie równy status obydwu partii pozwalał na uniknięcie sporów związanych z charakterem prowadzonych rozmów. Z drugiej, Kuomintang unikał kontroli i ewentualnych sprzeciwów ze strony opozycji, jakie byłyby możliwe w przypadku działań prowadzonych pod kierunkiem rządu odpowiadającego przed parlamentem.

Nowe możliwości instytucjonalizacji kontaktów pojawiły się dopiero wraz z dojściem do władzy Ma Ying-jeou w 2008 r. Dzięki temu, już z pozycji partii rządzącej, Kuomintang mógł zacząć wprowadzać w życie zalecenia, jakie zostały wypracowane w ramach wspomnianego wyżej dialogu z KPCh. Nie zarzucając kontaktów międzypartyjnych, po 9 latach przerwy wznowiono rozmowy SEF-ARATS. Ich owocem było podpisanie 18 porozumień dotyczących głównie wymiany gospodarczej i stanowiących w dużej mierze odpowiedź na potrzebę uregulowania wielu praktycznych kwestii, które od lat czekały na rozwiązanie (patrz tabela 8.2). Niewątpliwie najważniejszym z nich było podpisanie wspomnianego powyżej Porozumienia Ramowego o Współpracy Gospodarczej ponad Cieśniną Tajwańską, gdyż stwarzało ono podstawy do szeregu dalszych umów.

Tabela 8.2.

Szczyty SEF-ARATS w latach 2008-2012

\begin{tabular}{|c|c|c|}
\hline Data & Miejsce & Podpisany dokument \\
\hline 1 & 2 & 3 \\
\hline \multirow{2}{*}{$11-14.06 .2008$} & \multirow{2}{*}{ Pekin } & $\begin{array}{l}\text { „Protokół rozmów na temat lotów czarterowych ponad Cieśniną } \\
\text { Tajwańską” }\end{array}$ \\
\hline & & $\begin{array}{l}\text { „Porozumienie ponad Cieśniną Tajwańską dotyczące podróży } \\
\text { mieszkańców kontynentu na Tajwan” }\end{array}$ \\
\hline \multirow{4}{*}{$3-7.11 .2008$} & \multirow{4}{*}{ Tajpej } & $\begin{array}{l}\text { „Porozumienie ponad Cieśniną Tajwańską o bezpieczeństwie } \\
\text { żywności” }\end{array}$ \\
\hline & & „Porozumienie o transporcie lotniczym ponad Cieśniną Tajwańską” \\
\hline & & „Porozumienie o transporcie morskim ponad Cieśniną Tajwańską” \\
\hline & & „Porozumienie o usługach pocztowych ponad Cieśniną Tajwańską” \\
\hline \multirow{3}{*}{ 26.04.2009 } & \multirow{3}{*}{ Nankin } & $\begin{array}{l}\text { „Porozumienie o wspólnym zwalczaniu przestępczości ponad Cie- } \\
\text { śniną Tajwańską oraz pomocy prawnej” }\end{array}$ \\
\hline & & $\begin{array}{l}\text { „Porozumienie o współpracy w dziedzinie finansów ponad Cieśni- } \\
\text { ną Tajwańską" }\end{array}$ \\
\hline & & $\begin{array}{l}\text { „Uzupełniające porozumienie o transporcie lotniczym ponad Cie- } \\
\text { śniną Tajwańską" }\end{array}$ \\
\hline
\end{tabular}


Tabela 8.2 (cd.)

\begin{tabular}{|c|c|c|}
\hline 1 & 2 & 3 \\
\hline \multirow{3}{*}{$24-25.12 .2009$} & \multirow{3}{*}{$\begin{array}{l}\text { Taichung } \\
\text { (Taizhong) }\end{array}$} & $\begin{array}{l}\text { „Porozumienie o współpracy ponad Cieśniną Tajwańską w zakresie } \\
\text { kwarantanny i inspekcji produktów rolnych” }\end{array}$ \\
\hline & & $\begin{array}{l}\text { „Porozumienie o współpracy ponad Cieśniną Tajwańską w zakresie } \\
\text { standardów, miar i wag oraz inspekcji i akredytacji” }\end{array}$ \\
\hline & & $\begin{array}{l}\text { „Porozumienie o współpracy ponad Cieśniną Tajwańską w sprawach } \\
\text { załóg statków rybackich” }\end{array}$ \\
\hline \multirow{2}{*}{$28-30.06 .2010$} & \multirow{2}{*}{$\begin{array}{l}\text { Chon- } \\
\text { gqing }\end{array}$} & $\begin{array}{l}\text { „Porozumienie Ramowe o Współpracy Gospodarczej ponad Cieśni- } \\
\text { ną Tajwańską” (ECFA) }\end{array}$ \\
\hline & & $\begin{array}{l}\text { „Porozumienie o współpracy ponad Cieśniną Tajwańską w ochrony } \\
\text { praw własności intelektualnej” }\end{array}$ \\
\hline $20-22.12 .2010$ & Tajpej & $\begin{array}{l}\text { „Porozumienie o współpracy ponad Cieśniną Tajwańską w zakresie } \\
\text { medycyny i zdrowia” }\end{array}$ \\
\hline 19-21.10.2011 & Tianjin & $\begin{array}{l}\text { „Porozumienie o współpracy w zakresie bezpieczeństwa energetyki } \\
\text { jądrowej” }\end{array}$ \\
\hline \multirow{2}{*}{ 8-9.08.2012 } & \multirow{2}{*}{ Tajpej } & $\begin{array}{l}\text { „Porozumienie o współpracy ponad Cieśniną Tajwańską w zakresie } \\
\text { ochrony inwestycji” (uzupełniające ECFA) }\end{array}$ \\
\hline & & $\begin{array}{l}\text { „Porozumienie o współpracy celnej ponad Cieśniną Tajwańską” } \\
\text { (uzupełniające ECFA) }\end{array}$ \\
\hline
\end{tabular}

Źródło: opracowanie własne autora.

Po podpisaniu ECFA nastąpił również dalszy rozwój instytucjonalizacji poprzez powołanie pierwszego wspólnego ciała oraz zainicjowanie tworzenia biur przedstawicielskich po obydwu stronach Cieśniny. W myśl postanowień ECFA powstał Komitet Współpracy Gospodarczej ponad Cieśniną Tajwańską (Liang'an Jingji Hezuo Weiyuanhui), którego podstawowym zadaniem stało się czuwanie nad wprowadzeniem w życie oraz przestrzeganiem zapisów porozumienia ramowego. W latach 2011-2012 doszło łącznie do czterech spotkań Komitetu, na przemian na Tajwanie i w Chinach kontynentalnych ${ }^{29}$, a jednym z najważniejszych ustaleń, jakie wówczas podjęto, była decyzja z listopada 2011 r. o otwarciu przedstawicielstw instytucji wspierających inwestycje bezpośrednie. W tym miejscu należy jednak zwrócić uwagę, iż Tajwańska Rada Rozwoju Handlu Zagranicznego (TAITRA) otworzyła pierwsze biuro w Szanghaju dopiero 18 grudnia 2012 r., a jego chiński odpowiednik nie rozpoczął działalności w Tajpej do końca 2012 r.

Czas potrzebny na otwarcie przedstawicielstw zajmujących się nawet niekontrowersyjnymi obszarami pokazuje jednak, jak złożonym i wymagającym

29 ECFA „Liang'an Jingji Hezuo Weiyuanhui” zhijieshao [Wprowadzenie do „Komitetu Współpracy Gospodarczej ponad Cieśniną Tajwańską” ECFA], http://www.ecfa.org.tw/Committee. aspx?pid=6cid=14 [dostęp 20.12.2012]. 
szczególnej uwagi zagadnieniem jest instytucjonalizacja relacji ponad Cieśniną Tajwańską. Świadczy o tym również to, że dopiero w 2012 r. zaczęto poważnie przyglądać się problemowi otwarcia przedstawicielstw SEF i ARATS, co z pewnością byłoby przełomem, gdyż instytucje te faktycznie reprezentują rządy w pełnym zakresie spraw. Należy przy tym zwrócić uwagę, iż wszystkie wymienione wyżej inicjatywy powstały w oparciu o mechanizm funkcjonowania SEF i ARATS, zakładający dokonywanie ustaleń $\mathrm{w}$ drodze negocjacji na równych prawach, za pośrednictwem oddelegowanych przez władze instytucji formalnie pozarządowych ${ }^{30}$.

Nie można również zapomnieć o tym, iż od 2008 r. zaczęto wykorzystywać również nieformalne okazje do spotkań liderów. Przede wszystkim dotyczy to Azjatyckiego Forum Ekonomicznego w Boao na chińskiej wyspie Hajnan ${ }^{31}$ oraz szczytów Wspólnoty Gospodarczej Azji i Pacyfiku (APEC). Szczególnie istotna okazała się pierwsza z wymienionych, gdyż w 2008 i 2012 r. do Boao udali się tajwańscy wiceprezydenci elekci, aby spotkać się z przywódcami chińskimi. W 2008 r. Vincent Siew spotkał się z przewodniczącym Hu Jintao ${ }^{32}$, w 2012 r. Wu Den-yih z wicepremierem Li Keqiangiem. W latach 2008-2012 wysłannikiem tajwańskiego prezydenta na szczyty APEC był z kolei Lien Chan, były wiceprezydent i honorowy przewodniczący KMT (z powodów politycznych tajwańska głowa państwa nie może w nich uczestniczyć osobiście), który corocznie wykorzystywał tę okazję do spotkań z Hu Jintao, czyniąc z nich w praktyce stały kanał komunikacji ${ }^{33}$.

Warto również zauważyć, że w efekcie zmian na linii Pekin-Tajpej podwyższeniu uległ również status relacji pomiędzy Tajwanem a Hongkongiem i Makao.

${ }^{30} \mathrm{Z}$ podobnym opóźnieniem mieliśmy do czynienia w maju 2010 r., kiedy powstały biura przedstawicielskie zajmujące się promocją turystyki - stało się prawie rok po ogłoszeniu takiego zamiaru. Były to również przedstawicielstwa formalnie niezależnych instytucji zajmujących się promocją turystyki ponad Cieśniną Tajwańską. W Pekinie otwarto biuro Stowarzyszenia Turystyki ponad Cieśniną Tajwańską (Taiwan Haixia Liang'an Guanguang Luyou Xiehui), kolejne otwarto w 2012 r. w Szanghaju, w Tajpej zaś Stowarzyszenia Wymiany Turystycznej ponad Cieśniną Tajwańską (Taiwan Haixia Liang'an Luyou Jiaoliu Xiehui).

31 Rozwiązanie to różniło się o stosowanych przez Chiny np. wobec Hongkongu.

32 Będące odpowiednikiem Forum Ekonomicznego w Davos jest organizowane corocznie na wyspie Hajnan. Tajwańczycy byli na nim obecni od pierwszej edycji w 2002 r. Jest przede wszystkim forum biznesowe, przeznaczone dla przedsiębiorców, zawsze gościli na nim jednak najważniejsi chińscy politycy.

33 Należy zwrócić uwagę, iż od 2002 r. delegacje tajwańskie na forum Boao były organizowane przez Fundację Wspólnego Rynku ponad Cieśniną Tajwańską (Liang'an Gongtong Shichang Jijinhui), kierowaną właśnie przez Vincenta Siewa, który dzięki temu był stałym gościem forum. W trakcie spotkania w $2008 \mathrm{r}$. Hu Jintao zapowiedział realizację większości późniejszych inicjatyw, m.in. wznowienia rozmów SEF-ARATS, lotów ponad Cieśniną Tajwańską, wysyłania chińskich turystów na Tajwan itd. Zob. Hu Calls for Further Mainland-Taiwan Cooperation, Xinhua, 12.04.2008, http://news.xinhuanet.com/english/2008-04/13/content_7966466.htm [dostęp 17.11.2012]. 
W lipcu 2011 r. władze obydwu specjalnych regionów autonomicznych zgodziły się na przemianowanie przedstawicielstw tajwańskich na Biura Gospodarcze i Kulturalne Tajpej ${ }^{34}$, same zaś otworzyły stałe przedstawicielstwa w Tajpej w grudniu tego samego roku. Nastąpiły przy tym pierwsze w historii wymiany wizyt na szczeblu ministerialnym, podjęto też nowe inicjatywy w zakresie rozwoju wymiany gospodarczej. Powyższe zmiany z całą pewnością nie byłyby możliwe, gdyby sprzeciwiał się im Pekin.

Tabela 8.3.

Instytucjonalizacja relacji ponad Cieśniną Tajwańską po 2005 r.

\begin{tabular}{|c|c|c|c|c|}
\hline Rok & Spotkanie liderów & SEF-ARATS & KPCh-KMT & Forum Boao \\
\hline 2005 & $\begin{array}{l}\text { Hu Jintao - Lien Chan } \\
\text { Hu Jintao - Soong Chu-yu }\end{array}$ & & & \\
\hline 2006 & & & $\begin{array}{l}\text { Pekin } \\
\text { Boao }\end{array}$ & \\
\hline 2007 & & & Pekin & \\
\hline 2008 & $\begin{array}{l}\text { Hu Jintao - Lien Chan (APEC) } \\
\text { Hu Jintao - Wu Po-hsiung }\end{array}$ & $\begin{array}{l}\text { Pekin } \\
\text { Tajpej }\end{array}$ & Szanghaj & $\begin{array}{l}\text { Hu Jintao-Vincent } \\
\text { Siew }\end{array}$ \\
\hline 2009 & Hu Jintao - Wu Po-hsiung & $\begin{array}{l}\text { Nankin } \\
\text { Taichung }\end{array}$ & Changsha & \\
\hline 2010 & $\begin{array}{l}\text { Hu Jintao - Lien Chan, } \\
\text { Hu Jintao -Wu Po-hsiung } \\
\text { (EXPO) }\end{array}$ & $\begin{array}{l}\text { Chongqing } \\
\text { Tajpej }\end{array}$ & Kanton & \\
\hline 2011 & $\begin{array}{l}\text { Hu Jintao - Lien Chan (APEC) } \\
\text { Hu Jintao - Wu Po-hsiung }\end{array}$ & Tianjin & Chengdu & \\
\hline 2012 & Hu Jintao - Wu Po-hsiung & Tajpej & Harbin & $\begin{array}{l}\text { Li Keqiang - Wu } \\
\text { Den-yih }\end{array}$ \\
\hline
\end{tabular}

Źródło: opracowanie własne autora.

\section{Udział w pracach organizacji międzynarodowych}

Przechodząc do kwestii wspólnego udziału w pracach organizacji międzynarodowych należy podkreślić, że izolacja międzynarodowa Tajwanu stanowi

34 O postępie, jaki dokonał się w tym wymiarze, może świadczyć fakt, iż w 2001 r. podczas szczytu APEC w Szanghaju strona chińska nie zgodziła się na przyjazd Li Yuan-tsu, byłego wiceprezydenta Tajwanu (w latach 1990-1996) w charakterze szefa delegacji tajwańskiej. W efekcie Tajwan zbojkotował to wydarzenie. Z drugiej strony, po 2008 r. Pekin nie zgodził się na reprezentowanie Tajwanu przez urzędującego prezydenta ani przez wskazanego w pierwszej kolejności Fredricka Chena, ministra spraw zagranicznych. Zob. P. Chang, Taiwan's APEC Envoy Was Always a PRC Pick, „Taipei Times”, 15.11.2009, http://www.taipeitimes.com/News/editorials/archives/2009/11/15/2003458503 [dostęp 10.01.2013]. 
jeden z trzech najważniejszych elementów chińskiej strategii zjednoczeniowej, obok uzależnienia gospodarczego i zastraszenia użyciem siły. Przy czym z punktu widzenia Pekinu izolacja międzynarodowa bezpośrednio przyczynia się do zjednoczenia państwa, gdyż, jak zakładają władze ChRL, pozbawiony wsparcia z zewnątrz Tajwan, będzie zmuszony zwrócić się w stronę zjednoczenia. Wynika to z faktu, że w ocenie chińskiej siły proniepodległościowe na Tajwanie utrzymują się dzięki wsparciu płynącemu z zagranicy, stąd skuteczne blokowanie Tajwanu w stosunkach międzynarodowych powinno przyczynić się do zneutralizowania przeciwników zjednoczenia na samej wyspie.

Rywalizacja pomiędzy Pekinem a Tajpej w obszarze polityki międzynarodowej sięga przy tym początków współczesnego sporu o Tajwan i dotyczy dwóch zasadniczych aspektów - dyplomacji dwustronnej oraz członkostwa w organizacjach międzynarodowych. W swojej pierwotnej formie, walki o prawo do reprezentowania Chin w stosunkach międzynarodowych, zakończyła się ona jednak w 1979 r., po tym, jak Stany Zjednoczone formalnie przeniosły uznanie na rząd pekiński, przypieczętowując tym samym zwycięstwo komunistów, którego symbolem było również zasiadanie w Radzie Bezpieczeństwa ONZ w charakterze stałego członka (od 1971 r.). Wraz z końcem zimnej wojny i transformacją ustrojową na Tajwanie problem powrócił w zmienionej formie.

Demokratyzacja Tajwanu, obok zmiany paradygmatu sporu z Pekinem, przyczyniła się również do zredefiniowania aspektu dyplomatycznego relacji ponad Cieśniną Tajwańską. Rosnący na znaczeniu gospodarczym Tajwan, z jednej strony, potrzebował większego zabezpieczenia własnych interesów, z drugiej - zyskał do tego odpowiednie środki. Panujący dysonans pomiędzy zajmowaną w świecie pozycją gospodarczą a polityczną przełożył się na oczekiwania obywateli, aby już demokratyczny rząd poszukał drogi do przełamania izolacji Pekinu. W efekcie, od początku lat 90. rząd Tajwanu zaczął intensywnie zabiegać o członkostwo w organizacjach międzynarodowych, na czele z ONZ, już nie jako jedyny reprezentant Chin, ale jako przedstawiciel $23 \mathrm{mln}$ mieszkańców wyspy. Naturalnie spotkało się to ze stanowczym sprzeciwem Pekinu, który widział w tych działaniach drogę do formalnej niepodległości Tajwanu ${ }^{35}$.

Wysiłki w kierunku zwiększenia obecności międzynarodowej Tajwanu były kontynuowane po 2000 r. i dojściu do władzy Chen Shui-biana. Obok trwającej dalej rywalizacji o uznanie dyplomatyczne, Tajwan intensywnie zabiegał również o możliwość uczestniczenia w pracach organizacji międzynarodowych. Przede wszystkim dotyczyło to Światowej Organizacji Zdrowia, kontynuowano również próby wstąpienia do Organizacji Narodów Zjednoczonych. Pekin jednak w większym stopniu, niż miało to miejsce wcześniej, zaczął wykorzystywać państwa trzecie do wywierania presji na Tajwan, skutecznie blokując tym samym tajwańskie inicjatywy.

35 T.Y. Wag, Taiwan's Bid for UN Membership, [w:] E. Friedman, China's Rise..., s. 174-176. 
Izolacja wyspy nigdy nie była jednak zupełna, a w omawianym okresie przedstawiciele rządów z obydwu stron Cieśniny uczestniczyli nawet w pracach tych samych organizacji. Najważniejszym sprawdzianem dla jednoczesnego funkcjonowania w jednej organizacji międzynarodowej było członkostwo Chin oraz Tajwanu w Światowej Organizacji Handlu (WTO, World Trade Organization). Chińska Republika Ludowa wstąpiła do niej 11 grudnia 2001 r., a Tajwan 1 stycznia 2002 r. jako „Odrębne Terytorium Celne Tajwanu, Penghu, Kinmenu i Matsu” (OTCTPKiM). Choć nie był to pierwszy przypadek jednoczesnego członkostwa ${ }^{36}$, to uwzględniając skalę oraz zakres działalności WTO (zaliczającej się do najważniejszych organizacji międzynarodowych o zasięgu światowym), stanowił on interesujące studium przypadku współobecności obydwu stron Cieśniny w znaczącej organizacji międzynarodowej, o dużym zakresie uregulowań i procedur wewnętrznych, którym członkowie musieli się podporządkować.

Należy przy tym podkreślić, iż Tajpej wstępując do WTO, nie zastrzegło wyłączenia relacji gospodarczych z Chinami spod norm tej organizacji. Wynikało to przede wszystkim z chęci wykorzystania forum międzynarodowego do prowadzenia oficjalnych rozmów ze stroną chińską, w których Tajwańczycy mieliby równy status i nie byli blokowani przez warunki wstępne (obok tego argumentu liczono również na znaczące zyski ze zwiększonej wymiany handlowej) ${ }^{37}$. Chińczycy godząc się na wstąpienie Tajwanu do WTO, mieli jednak odmienne spojrzenie na kwestie prowadzenia rozmów dwustronnych z Tajwańczykami. Uważali, że sami zostali członkiem organizacji jako suwerenne państwo, podczas gdy Tajwan jako chińskie odrębne terytorium celne, przez co nie uległ zmianie charakter relacji gospodarczych ponad Cieśniną Tajwańską, które powinny być prowadzone w ramach ,jednych Chin”.

Z czasem Chińczycy złagodzili swoje pierwotne stanowisko, dopuszczając negocjacje w ramach WTO, ściśle przestrzegając przy tym założeń polityki jednych Chin. Podkreślić należy, iż problemem dla Pekinu było przede wszystkim zastosowanie reguł organizacji międzynarodowej do kontaktów dwustronnych. Chiny, zgodnie z procedurami WTO, przeprowadzały zatem konsultacje i wysyłały noty, podkreślając jednak własne stanowisko wobec kwestii tajwańskiej poprzez prowadzenie korespondencji w języku chińskim, tytułowanie Stałego Przedstawicielstwa OTCTPKiM „Biurem Gospodarczym” (taki status posiadają przedstawicielstwa Hongkongu i Makao przy WTO) oraz skracając nazwę OTCTPKiM jako „Chińskie Tajpej”. Zabiegi te miały na celu przedstawienie przez Chiny kontaktów ze stroną tajwańską w ramach organizacji międzynarodowych jako wewnętrznych.

36 Jedynymi bardziej znaczącymi organizacjami były: Azjatycki Bank Rozwoju (ADB - Asian Development Bank) oraz Wspólnota Gospodarcza Azji i Pacyfiku (APEC - Asia Pacific Economic Co-operation).

${ }_{37}$ H. Cho, China-Taiwan Tug of War in the WTO, „Asian Survey” 2005, vol. 45, issue 5, s. $742-743$. 
Ogólna poprawa klimatu relacji ponad Cieśniną Tajwańską po objęciu urzędu prezydenta przez Ma Ying-jeou, zauważalna we wspomnianej wcześniej instytucjonalizacji, przełożyła się również na problematykę międzynarodowej obecności Tajwanu. Przede wszystkim doszło do faktycznego, lecz niepotwierdzonego oficjalnie „rozejmu dyplomatycznego” (waijiao xiubing), polegającego na zaprzestaniu przez zainteresowane strony rywalizacji o uznanie dyplomatyczne. W efekcie, w latach 2008-2012 nie doszło do żadnych zmian w uznawaniu rządu w Tajpej, a liczba państw utrzymujących relacje dyplomatyczne z Tajwanem wynosiła w tym okresie niezmiennie 23. Stało się tak pomimo zabiegów niektórych państw, w szczególności z Ameryki Łacińskiej, o nawiązanie stosunków z ChRL.

Samoograniczenie się Pekinu w tym względzie niewątpliwie miało służyć osiągnięciu innych celów w czasie pierwszej kadencji Ma, a w szczególności, doprowadzić do podpisania budzącego kontrowersje i obawy dużej części społeczeństwa tajwańskiego ECFA. Ma potrzebował jednak w tym celu sukcesów w ważnym dla wyborców obszarze obecności międzynarodowej Tajwanu. Symboliczne w tym względzie stało się również przyznanie w 2009 r. Tajwanowi, jako Chińskiemu Tajpej, statusu obserwatora podczas Światowego Zgromadzenia Zdrowia (WHA - World Health Assembly) ${ }^{38}$. W tym wypadku również odbyło się to dzięki zgodzie Chin.

Choć formalnie Chiny nie zmieniły swojego stanowiska odnośnie do członkostwa Tajwanu w organizacjach międzynarodowych zrzeszających państwa, po 2008 r. Pekin zaczął wysyłać sygnały świadczące o tym, że jest gotów do rozważenia tej kwestii ${ }^{39}$. Stało się to jednak wówczas, kiedy Chiny potwierdziły faktyczne

38 Trzeba jednak zaznaczyć, iż był to przypadek wyjątkowy i trudny do powtórzenia w przypadku innych organizacji międzynarodowych. Po pierwsze, wyjątkowa jest struktura decyzyjna samej organizacji, m.in. dlatego, że WHA nie jest ciałem stałym, lecz zbierającym się raz do roku. Dodatkowo, za każdym razem wystosowywane są nowe zaproszenia do uczestniczenia w obradach (możliwe jest zatem wpłynięcie przez Chiny na niezaproszenie Tajwanu). Po drugie, kwestie zdrowotne wymagają powszechnej współpracy, w innym wypadku narażają działania np. w obszarze ochrony epidemiologicznej na fiasko. Stąd też Chiny odczuwały naciski ze strony pozostałych państw, zwłaszcza od czasu epidemii SARS z 2003 r. Zob. J. deLisle, Taiwan in the World Health Assembly: A Victory, with Limits, [w:] Brookings Northeast Asia Commentary, no. 29, May 2009, http://www.brookings.edu/research/opinions/2009/05/taiwan-delisle [dostęp 20.06.2012].

$39 \mathrm{~W}$ uznawanym za programowe w odniesieniu do relacji z Tajwanem po $2008 \mathrm{r}$. przemówieniu Hu Jintao z okazji 30. rocznicy wydania „Odezwy do rodaków na Tajwanie” przywódca chiński powiedział: „Rozumiemy uczucia naszych tajwańskich rodaków związane z uczestniczeniem w działalności międzynarodowej i poświęcamy szczególną uwagę rozwiązywaniu odpowiednich kwestii. (...) W odniesieniu do kwestii uczestnictwa Tajwanu w pracach organizacji międzynarodowych, uczciwe i rozsądne ustalenia mogą być osiągnięte poprzez pragmatyczne konsultacje pomiędzy dwiema stronami pod warunkiem, że nie doprowadzą do powstania »dwóch Chin« lub »jednych Chin i jednego Tajwanu«. Zob. Let Us Join Hands to Promote the Peaceful Development of Cross-Straits Relations and Strive with a United Resolve for the Great Rejuvenation of the Chinese Nation, December 31, 2008, http://www.gwytb.gov.cn/en/Special/Hu/201103/t20110322_1794707. htm [dostęp 15.01.2013]. 
sprowadzenie kwestii uczestniczenia przez Tajwan w pracach organizacji międzynarodowych do poziomu relacji ponad Cieśniną Tajwańską. Sprawa Światowego Zgromadzenia Zdrowia pokazała bowiem, że społeczność międzynarodowa nie jest w stanie wpłynąć na pozytywne dla Tajpej rozwiązanie w sytuacji, gdy sprzeciwia się temu Pekin. Zależność ta została potwierdzona przy okazji późniejszych dążeń Tajwanu do znaczącego udziału (meaningful participation) w Organizacji Międzynarodowego Lotnictwa Cywilnego (ICAO).

\section{Ideologiczno-kulturowe}

Obszar ten stanowi specyficzne wyzwanie, wynikające w dużej mierze z faktu istnienia na Tajwanie silnej tożsamości tajwańskiej, budowanej na opozycji wobec chińskości, w tym także tej łączonej z dziedzictwem ChRL. Poza tym, choć obydwie strony łączy wspólna chińska tradycja kulturowa i język, to odmienność doświadczeń po $1949 \mathrm{r}$. spowodowała znaczne oddalenie się również w tym wymiarze. Nie można przy tym zapominać o dużej atrakcyjności tajwańskiej kultury popularnej w Chinach, co utrudnia dotarcie $\mathrm{z}$ podobnym przekazem $\mathrm{w}$ drugą stroną. W efekcie, choć w połowie lat 80 . zakładano rozpoczęcie przywracania łączności pomiędzy Chinami kontynentalnymi i Tajwanem właśnie od wymiany kulturalnej, to w praktyce obszar ten okazał się zbyt drażliwy i nie dorównywał kontaktom gospodarczym.

Poza ogólnymi wypowiedziami przywódców chińskich o potrzebie rozwoju tego obszaru relacji ponad Cieśniną Tajwańską, trudno zauważyć skoordynowane działania mające na celu promowanie kultury chińskiej w wydaniu kontynentalnym. W 2010 r. miała jednak miejsce wizyta chińskiego ministra kultury na Tajwanie, będąca pierwszą od 12 lat wizytą chińskiego ministra na wyspie. Z drugiej strony, odbyła się ona na zaproszenie prywatnej fundacji działającej na rzecz wymiany kulturalnej, a nie rządu (choć doszło do spotkania z jego tajwańskim odpowiednikiem $)^{40}$. Strona chińska sygnalizowała przy tej okazji potrzebę zawarcia umowy o wymianie kulturalnej wzorowanej na ECFA, w omawianym okresie Tajwańczycy odrzucali jednak taką możliwość (głównym argumentem był brak dotychczasowej współpracy pomiędzy agendami rządowymi ${ }^{41}$.

Na wyróżnienie w obszarze kultury, głównie ze względów symbolicznych, zasługuje nawiązana w 2009 r. współpraca pomiędzy najważniejszymi muzeami chińskimi, z Muzeum Pałacowym w Pekinie na czele, z główną placówką muzealną Tajwanu, Muzeum Pałacowym w Tajpej. Organizowane są wspólne wystawy, choć z powodu obaw tajwańskich ograniczały się one w omawianym okresie

40 China's Culture Minister Visits Taiwan, „The China Post”, 3.9.2010, http://www.chinapost. com.tw/taiwan/china-taiwan-relations/2010/09/03/271173/Chinas-culture.htm [dostęp 30.01.2013].

${ }^{41}$ No Urgent Need for Taiwan-China Cultural Pact: SEF, „Focus Taiwan”, 23.01.2013, http://focustaiwan.tw/ShowNews/WebNews_Detail.aspx?ID=201301230038\&Type=aIPL [dostęp 30.01.2013]. 
do wypożyczania eksponatów przez muzea chińskie ${ }^{42}$. Warto przy tym zwrócić uwagę, iż dokonując wyboru prezentowanych dzieł sztuki, często kierowano się nawiązywaniem do jedności, $w$ tym tak bezpośrednio, jak poprzez wypożyczenie jednej części rozdzielonego zwoju, dzięki czemu po raz pierwszy od setek lat można go było obejrzeć w całości ${ }^{43}$.

\section{Wojskowe}

Najważniejszym narzędziem wojskowym w odniesieniu do Tajwanu pozostawała niezmiennie chińska odmowa wyrzeczenia się stosowania siły oraz uwiarygodniające je stałe rozbudowywanie ofensywnego potencjału wojskowego. Postawa taka wynikała z istniejącego po 1979 r. wśród chińskich elit władzy konsensusu co do konieczności stosowania elementu nacisku, bez którego opcja pokojowa ${ }^{44}$ nie przyniesie pożądanych rezultatów ${ }^{45}$. W związku z tym unowocześnianie armii miało na celu głównie odstraszenie Tajwańczyków i państw trzecich od podejmowania działań w kierunku trwałego oddzielenia wyspy od Chin, z drugiej zaś strony miało jednak pozwolić na zbrojne sprzeciwienie się temu, gdyby wspomniane środki zawiodły ${ }^{46}$.

Powyższa koncepcja została w omawianym okresie rozwinięta przez $\mathrm{Hu}$ Jintao w ramach jego programu polityki wobec Tajwanu, określanego w literaturze przedmiotu jako „twarde twardsze, miękkie bardziej miękkie”. Opisanym we wcześniejszych częściach chińskim inicjatywom mającym na celu zjednanie Tajwańczyków towarzyszyło bowiem dalsze wzmacnianie nacisku wojskowego. Procesy te były przy tym ściśle ze sobą powiązane. Zintensyfikowanie dialogu międzypartyjnego wiosną 2005 r. poprzedzało usztywnienie stanowiska chińskiego w odniesieniu do niepodległości Tajwanu. Służyła temu deklaracja Hu Jintao w przemówieniu z 4 marca 2005 r. (jego główne założenie znane są jako „cztery punkty Hu”), mówiąca o tym, że Chiny nigdy: nie porzucą doktryny ,jednych Chin”, nie zaprzestaną wysiłków na rzecz zjednoczenia, nie przestaną pokładać

42 China to Lend National Palace Museum Historic Artifacts, Museum Director Says, „Taipei Times", 21.01.2013, http://www.taipeitimes.com/News/taiwan/archives/2013/01/21/2003553066 [dostęp 31.1.2013].

${ }^{43}$ Landscape Reunited. Introduction, National Palace Museum, http://www.npm.gov.tw/ exh100/fuchun/en_01.html [dostęp 31.1.2013].

44 Należy przy tym zaznaczyć, że chińskie rozumienie „pokojowego” zakończenia sporu dopuszcza uzyskanie takiego rezultatu również poprzez przymus i zastraszenie, co wynika z głęboko zakorzenionego w chińskiej myśli strategicznej podejścia do prowadzenia wojny, w którym szczególnie cenione jest poddanie się wroga bez walki.

45 J. You, Changing Leadership Consensus. The Domestic Context of War Games, [w:] S. Zhao (red.), Across the Taiwan Strait. Mainland China, Taiwan, and the 1995-1996 Crisis, New YorkLondon 1999, s. 78.

46 A.M. Wachman, Why Taiwan? Geostrategic Rationales for China's Territorial Integrity, Stanford University Press, Stanford 2007, s. 16. 
nadziei w mieszkańcach Tajwanu oraz nie wycofają swojego sprzeciwu wobec niepodległości Tajwanu ${ }^{47}$.

Jednym z najważniejszych wydarzeń okresu rządów Hu Jintao w odniesieniu do Tajwanu była Ustawa antysecesyjna, sankcjonująca obowiązek użycia siły przez władze chińskie w celu powstrzymania niepodległości Tajwanu. Obok treści, należy jednak zwrócić uwagę również na okoliczności jej uchwalenia. Z jednej strony, wpisywała się ona w zmiany w planowaniu wojskowym, jakie zaszły w Chinach w pierwszych latach XXI w. Z drugiej zaś, stanowiła jeden z elementów wspomnianej już modyfikacji chińskiej polityki wobec Tajwanu ${ }^{48}$ (niektórzy badacze wskazują nawet na Ustawę antysecesyjna jako w większym stopniu manifest polityczny nowego przywódcy niż prawo ${ }^{49}$ ). Jasno wskazując w niej wroga, jakim były siły dążące do oderwania Tajwanu od Chin, spełniono wymagania taktyki zjednoczonego frontu, konieczne do nawiązania dialogu z ówczesnymi tajwańskimi partiami opozycyjnymi.

Podwaliny dla twardszej polityki wobec Tajwanu dała jednak nowa strategia obronna ChAL-W, przyjęta w 2002 r. Wskazano w niej na separatystów tajwańskich jako największe zagrożenie dla pokoju w Cieśninie Tajwańskiej oraz skrytykowano państwa, które sprzedają Tajwanowi broń i podsycają siły proniepodległościowe ${ }^{50}$. Ustawa antysecesyjna uwzględniała też nową koncepcję prowadzenia wojny, w szczególności budowanie podstaw prawnych do włączenia się w konflikt zbrojny ${ }^{51}$. Nowe „Wytyczne pracy politycznej ChAL-W” (Zhongguo Jiefangjun Zhengzhi Gongzuo Tiaoli) ${ }^{52}$ z grudnia 2003 r. wskazywały na szczególną rolę wojny medialnej, psychologicznej i prawnej ${ }^{53}$.

${ }^{47}$ Four-Point Guidelines on Cross-Straits Relations Set Forth by President Hu (Full Text), http://www.gwytb.gov.cn/en/Special/OneChinaPrinciple/201103/t20110317_1790120.htm. [dostęp 31.1.2013].

48 Warto przy tym zwrócić uwagę na fakt uchwalenia ustawy zaledwie dzień po objęciu przez Hu Jintao stanowiska przewodniczącego Centralnej Komisji Wojskowej (państwowej), co niewątpliwie potwierdzało przejęcie przez niego pełni władzy w Chinach, w tym w kwestii tajwańskiej.

49 J. You, China's Anti-Secession Law and the Risk of War in the Taiwan Strait, „Contemporary Security Policy" 2006, vol. 27, no. 2, s. 238.

50 China's National Defense in 2002, http://www.china.org.cn/e-white/20021209/I.htm [dostęp 18.06.2012].

51 Wpływ na przyspieszenie prac nad nią w dużej mierze miała druga wojna w Zatoce Perskiej i amerykańskie działania na rzecz uzasadnienia interwencji. Zob. Ch. Lin, Hu Making His Own Taiwan Policy, „Taipei Times”, http://www.taipeitimes.com/News/editorials/archives/2005/03/26/2003247866 [dostęp 20.12.2011].

52 Zhonggong Zhongyang guanyu banbu ,Zhongguo Renmin Jiefang Jun Zhengzhi Gongzuo Tiaoli” de tongzhi [Komunikat KC KPCh dotyczący ogłoszenia „Wytycznych pracy politycznej Chińskiej Armii Ludowo-Wyzwoleńczej], 5.12.2003, http://cpc.people.com.cn/GB/64162/71380/1 02565/182142/10993467.html [dostęp 18.06.2012].

53 Warto zwrócić uwagę, że oprócz aspektu stricte prawnego, sposób przyjęcia Ustawy antysecesyjnej (wprowadzenie tematu do dyskusji medialnej, powtarzanie zapowiedzi) oraz wydarzenia 
Sama Ustawa składała się z zaledwie 10 artykułów. Kluczowy i wzbudzający najwięcej kontrowersji poza Chinami był art. 8, zawierający następującą zapowiedź: „W przypadku gdyby siły secesjonistyczne »niepodległości Tajwanu «", pod każdą nazwą i za pomocą każdych środków, doprowadziły do secesji Tajwanu od Chin, albo gdyby miały miejsce poważne incydenty prowadzące do secesji Tajwanu od Chin, lub gdyby całkowicie wyczerpano możliwości pokojowego zjednoczenia, państwo użyje środków niepokojowych lub innych koniecznych działań w celu ochrony suwerenności i niepodzielności Chin" ${ }^{54}$. Z jednej strony zapisano w niej zatem to, co było już jedną z podstaw polityki Chin wobec Tajwanu - niewyrzeczenie się stosowania siły. Z drugiej strony, zapis był jednak nieprecyzyjny, gdyż nieostre były zarówno kryteria stosowania siły, jak i sama odpowiedź Chin (wydaje się, że środki niepokojowe niekoniecznie muszą oznaczać użycie siły zbrojnej).

Co ważne, Chiny w całym omawianym okresie stale rozwijały siły wojskowe z przeznaczeniem użycia ich w ewentualnym konflikcie w Cieśninie Tajwańskiej. Nawet po 2008 r., kiedy w innych obszarach, nawet tak kontrowersyjnych z punktu widzenia Pekinu jak obecność międzynarodowa Tajwanu, nastąpiło wyjście naprzeciw oczekiwaniom Tajpej, w sferze obronności nie zaczęto rozwijać nawet środków budowy zaufania. Modernizowano przede wszystkim lotnictwo i marynarkę wojenną, a także budzące wśród społeczeństwa tajwańskiego największe obawy siły rakietowe. Według źródeł amerykańskich do października 2010 r. Chiny rozlokowały naprzeciw Tajwanu od 1000 do 1200 rakiet balistycznych krótkiego zasięgu, unowocześniając przy tym część wcześniej rozmieszczonych ${ }^{55}$. Stale utrzymywanych jest również ok. 400 tys. żołnierzy na obszarze sąsiadującym z Cieśniną Tajwańską ${ }^{56}$. Chiny nieprzerwanie prowadziły też intensywne działania wywiadowcze w obszarze obronności, stale rozwijając przy tym aparat stosowanych metod $^{57}$.

W omawianym okresie politykę Chin wobec Tajwanu niewątpliwie charakteryzowała niezmienność celu nadrzędnego, połączona z elastycznym podejściem do stosowanych narzędzi. Uwagę zwraca przede wszystkim łączne traktowanie

następujące po tym (nagradzanie współpracujących Tajwańczyków) w pełni wpisywały się opisane wyżej założenia, pokazując przy tym skuteczność nowej metody przy umiejętnym i uzupełniającym się użyciu poszczególnych elementów nowej koncepcji. Zob. T. Walton, Treble Spyglass, Treble Spear: China 's ,, Three Warfares”, „Defense Concepts”, 2010, vol. 4, ed. 4, s. 61-62.

54 „Fan Fenlie Guojia Fa” Quanwen [Pełny tekst „Ustawy antysecesyjnej”], http://www.fmprc.gov.cn/chn/pds/ziliao/tytj/t187116.htm [dostęp 15.06.2012].

55 Annual Report to Congress: Military and Security Developments Involving the People's Republic of China 2012, Office of the Secretary of Defense, May 2012, s. 21.

56 Ibidem, s. 27.

57 P. Mattis, Taiwan Espionage Cases Highlight Changes in Chinese Intelligence Operations, „China Brief”, 2011, vol. 11, issue 12, s. 4-7. 
poszczególnych środków; żaden nie był stosowany indywidualnie. Ogólna strategia, zawierająca się w jednoczesnym kierowaniu zachęt oraz wywieraniu presji, była spójna we wszystkich omawianych obszarach. Dużą rolę w gotowości Chin do ustępstw na rzecz Tajwanu odegrało pojawienie się wiarygodnego w oczach Pekinu partnera do rozmów. Dzięki temu możliwe było rozwinięcie polityki zjednoczonego frontu.

Trudno jednak ocenić efektywność polityki chińskiej wobec Tajwanu. Z jednej strony, od końca lat 80 . XX w. mamy do czynienia z nieprzerwanym pogłębianiem zależności łączących obydwie strony. W omawianym okresie doszło w tym względzie do faktycznego uzależnienia gospodarczego Tajwanu od Chin kontynentalnych, co czyni ewentualną niepodległość wyspy dużo kosztowniejszą. Z drugiej strony, badania socjologiczne postaw Tajwańczyków wobec własnej tożsamości oraz przyszłości Tajwanu i jego relacji z Chinami kontynentalnymi, a także wyniki wyborów wskazują na zwiększanie się dystansu pomiędzy obydwiema stronami Cieśniny Tajwańskiej. Pomimo poprawy relacji w 2008 r., nieprzerwanie rośnie bowiem odsetek osób uważających się za Tajwańczyków (w 2009 r. przekraczając barierę 50\%), spada z kolei tych, którzy w odległej perspektywie chcieliby zjednoczenia ${ }^{58}$. Twardy elektorat DPP z południa wyspy nadal głosuje zaś na kandydatów tej partii.

$\mathrm{Z}$ całą pewnością Hu Jintao udało się dokonać tego, czego nie osiągnął żaden z jego poprzedników: wznowił bowiem współpracę KPCh z KMT. Spotkał się z większą liczbą polityków tajwańskich niż jego poprzednicy, w tym m.in. z dwoma urzędującymi przewodniczącymi KMT i wiceprezydentem elektem. Jego rządy były czasem przełomowych wizyt, głównie Tajwańczyków w Chinach kontynentalnych. Pekin pokazał przy tym pragmatyzm, dowiódł również umiejętności poszukiwania dróg kontaktu poza oficjalnymi kanałami rządowymi.

${ }_{58}$ Taiwaness/Chinese Identification Trend Distribution in Taiwan (1992/06 2012/12) oraz Taiwan Independence vs. Unification with the Mainland Trend Distribution in Taiwan (1992/06 2012/12), przeprowadzone przez Election Study Center, National Chengchi University, http://esc.nccu.edu.tw/english/modules/tinyd2/index.php?id=6 [dostęp 30.01.2013]. 